\title{
META ANALISIS PENGARUH PENERAPAN PEMBELAJARAN BERBASIS KONSTRUKTIVISME PADA MATERI FISIKA DI KALIMANTAN BARAT
}

\author{
Boisandi ${ }^{1}$, Handy Darmawan ${ }^{2}$ \\ ${ }^{1,2}$ Pendidikan Fisika, Fakultas Pendidikan MIPA dan Teknologi, IKIP-PGRI Pontianak \\ Jalan Ampera Nomor 88 Pontianak, Indonesia. \\ e-mail: bsandi2012@gmail.com
}

Diterima: 4 Juli 2017. Disetujui: 7 Oktober 2017. Dipublikasikan: 28 Oktober 2017

\begin{abstract}
Abstrak: Penelitian ini bertujuan untuk mengetahui: (1) Rerata pengaruh pembelajaran berbasis konstruktivisme ditinjau dari jenjang pendidikan subjek penelitian (SMP dan SMA Sederajat). (2) Rerata pengaruh pembelajaran berbasis konstruktivisme ditinjau dari pemberian tindakan. (3) Rerata pengaruh pembelajaran berbasis konstruktivisme terhadap variabel terikat subjek penelitian. Metode penelitian ini adalah metode deskriptif kuantitatif. Sesuai dengan tujuan penelitian yang dikemukakan, maka subjek dalam penelitian ini diperoleh dari review laporan hasil penelitian sebanyak 5 (Lima) buah. Teknik pengumpulan data dalam meta analisis ini adalah observasi terhadap komponen-komponen yang diteliti pada beberapa laporan hasil penelitian dengan mengelompokkan berdasarkan kelompok-kelompok unit analisis. Hasil penelitian diperoleh Rerata pembelajaran berbasis konstruktivisme ditinjau dari jenjang pendidikan subjek penelitian, Rerata hasil belajar dan respon siswa dari pembelajaran berbasis konstruktivisme ditinjau dari pemberian tindakan, dan Rerata pengaruh pembelajaran berbasis konstruktivisme terhadap variabel terikat subjek penelitian berkategori baik.
\end{abstract}

Kata Kunci: fisika, konstruktivisme, meta analisis.

\section{META-ANALYSIS OF THE INFLUENCE OF CONSTRUCTIVISM- BASED LEARNING ON PHYSICS MATERIAL IN WEST KALIMANTAN}

\begin{abstract}
This study aims to determine: (1) average level of influence education to the subject of research (SMP and SMA equal) based constructivism. (2) average influence on giving action based constructivism. (3) Average influence on the learning toward dependent variable of subject research-based constructivism. The research method is quantitative descriptive. In accord with the purpose of the research, the subject in this study obtained from the review of 5 (Five) research results.The data collecting technique in this metaanalysis is an observation of the components examined in several reports of research results by a grouping of units-analysis. The research result obtained from the education level based constructivism, the average of learning outcomes and the students' responses based constructivism regarding giving the action, and the effect of learning based constructivism on the dependent variable is medium categorized.
\end{abstract}

(C) 2017 Pendidikan Fisika, FTK UIN Raden Intan Lampung

Keywords: physics, constructivism, meta-analysis.

\section{PENDAHULUAN}

Titik tolak dari implementasi pembelajaran sains harus sejalan dengan hakikat pembelajaran sains. Carin dan Evans menyatakan "Hakikat pembelajaran sains meliputi 4 hal yakni produk, proses, sikap dan teknologi". Pencapaian hakikat sains tidak luput dari penyelesaian masalah dalam proses pembelajaran yang menerapkan model yang sesuai dengan tujuan meningkatkan peran aktif peserta didik dalam pembelajaran agar pemahaman siswa terhadap materi tidak sekedar proses menghafal dan memahami tetapi juga dapat melakukan analisis, kajian, penemuan dan penerapan. (Abdurrahman, 2017; Nurussaniah \& Nurhayati, 2016; Rerung, Sinon, \& Widyaningsih, 2017; Suciati, 2010).

Idealnya pada proses pembelajaran siswa menjadi pusat perhatian utama, 
sedangkan Guru berperan sebagai fasilitator dengan cara memfasilitasi pembelajaran yang dapat memperkaya pengalaman belajar siswa (Erlinda, 2017; Matthew \& Kenneth, 2013; Rini, 2017; Ummi \& Mulyaningsih Indrya, 2016). Melalui pengalaman belajar yang mereka miliki, diharapkan dapat membangun konsep melalui pemecahan masalah (Ariesta \& Supartono, 2011; Syamsu, 2017). Hal ini sejalan dengan ide-ide konstruktivisme yaitu pelajar mengkonstruksikan pengetahuan untuk dirinya sendiri bukan mengandalkan pengetahuan yang didapat dari guru (Chujaemah, Yuliana, Utaminingsih, Triyono, \& Budi, 2013). Peserta didik diberikan keleluasaan untuk berinisiatif dan berpartisipasi di dalam kegiatan belajar.

Konstruktivis melihat belajar sebagai proses aktif pelajar mengkonstruksi arti baik dalam bentuk teks, dialog, pengalaman fisis, ataupun bentuk lainnya. Dalam perspektif konstruktivis, belajar bukan suatu perwujudan hubungan stimulus-respons. Fosnot menambahkan, tujuan belajar lebih difokuskan pada pengembangan konsep dan pemahaman yang mendalam daripada sekedar pembentukan perilaku atau keterampilan (Maryam, 2016; Sukiman, 2008).

Piaget, seorang tokoh konstruktivisme, menyatakan bahwa proses pengkonstruksian pengetahuan berlangsung melalui proses asimilasi dan akomodasi. Berdasarkan beberapa permasalahan dalam bidang pendidikan khususnya pendidikan fisika dalam proses pembelajaran, beberapa penelitian telah dilakukan dengan menerapkan modelmodel pembelajaran berbasis konstruktivisme (Rerung et al., 2017; Wati \& Fatimah, 2016).

Mengutip apa yang disampaikan oleh Carin dan Evans) tentang hakikat pembelajaran sains, dapat diartikan bahwa sains sebagai produk, berarti dalam sains terdapat fakta, hukum, prinsip, dan teori- teori yang sudah diterima kebenarannya. Sains sebagai proses artinya suatu metode untuk mendapatkan pengetahuan. Sains sebagai sikap artinya dalam sains terkandung pengembangan sikap ilmiah, dan sains sebagai teknologi artinya sains berkaitan erat dengan teknologi yang digunakan dalam kehidupan sehari-hari (Suciati, 2010).

Meta analisis dapat bersifat kuantitatif dan analisis statistik untuk memperoleh seri informasi yang berasal dari sejumlah data dari penelitian-penelitian sebelumnya (Sukamto, 1988). Meta analisis merupakan teknik pengembangan yang dapat membantu peneliti untuk menemukan kekonsistensian pengkajian hasil silang dari hasil penelitian. Meta analisis di penelitian ini berfokus pada data variabel penelitian, besar ukuran efek dan subjek penelitian. Berdasarkan uraian tersebut maka diperlukan penelitian yang bertujuan untuk menganalisis beberapa hasil penelitian yang membahas tentang pembelajaran berbasis konstruktivisme di beberapa tingkatan sekolah. Keseluruhan hasil penelitian ini mengungkapkan pengaruh pembelajaran berbasis konstruktivisme secara signifikan terhadap berbagai kemampuan siswa, yang pada akhirnya meningkatkan kualitas pembelajaran.

\section{METODE PENELITIAN}

Penelitian dilaksanakan di IKIP-PGRI Pontianak. Metode penelitian yang akan digunakan pada penelitian ini adalah metode deskriptif kuantitatif karena meta analisis adalah salah satu upaya untuk merangkum berbagai hasil penelitian secara kuantitatif (Nawawi, 2007; Sutjipto, 1995)

Teknik pengumpulan data yang digunakan dalam meta analisis ini adalah observasi terhadap komponen-komponen yang akan diteliti pada beberapa jurnal dan laporan hasil penelitian yang terdapat pada Lima laporan hasil penelitian dengan mengelompokkan berdasarkan kelompok- 
kelompok unit analisis. Instrument yang digunakan dalam pengumpulan data adalah lembar observasi dengan menggunakan pengkodean (coding data). Adapun variabel-variabel yang digunakan dalam pemberian kode data tentang besar pengaruh pembelajaran berbasis konstruktivisme antara lain: (a) Nama peneliti dan tahun; (b) jenjang pendidikan subjek penelitian; (c) pemberian tindakan; (d) variabel bebas penelitian; (e) variabel terikat penelitian. Teknik analisis data yang digunakan dalam penelitian ini adalah teknik statistik deskriptif. Teknik ini digunakan untuk menghitung besar pengaruh (Effect size) pembelajaran Fisika berbasis konstruktivisme dengan menggunakan rumus Cohen (Saregar, Latifah, \& Sari, 2016; Wati \& Fatimah, 2016) sebagai berikut

$$
d=\frac{\text { Mposttest }- \text { Mpretest }}{\sqrt{\frac{\text { SD } D^{2} \text { posttest }+S D^{2} \text { pretest }}{2}}}
$$

Keterangan:

$\mathrm{M}=$ Rata-rata skor tes

$\mathrm{D}=$ Standar Deviasi skor test

HASIL DAN PEMBAHASAN

\section{Hasil Penelitian}

Hasil penelitian yang telah tersusun diantaranya;

\section{Kriteria Pemilihan Artikel}

Kriteria pemilihan artikel dalam penelitian ini mencakup beberapa hal seperti di bawah ini :

a. Artikel yang dipilih merupakan hasil penelitian yang telah dan belum terpublikasi.

b. Artikel yang dipilih menggunakan pembelajaran berbasis konstruktivisme sebagai variabel bebas dalam penelitian.

c. Artikel yang dipilih menggunakan hasil belajar dan respon siswa sebagai variabel terikat dalam penelitian.

2. Artikel yang dipilih menggunakan siswa pada jenjang SMP dan SMA sederajat sebagai subyek penelitian.

3. Penelusuran Laporan Penelitian Penelusuran laporan penelitian disusun berdasarkan pengkodean laporan penelitian yang diperoleh berdasarkan observasi yang dilakukan. Berikut disajikan hasil penelusuran laporan penelitian.

Tabel 1. Penelusuran Hasil Penelitian

\begin{tabular}{|c|c|c|c|c|c|}
\hline No & $\begin{array}{c}\text { Nama } \\
\text { peneliti/Tahun }\end{array}$ & $\begin{array}{c}\text { Jenjang } \\
\text { pendidikan } \\
\text { subjek } \\
\end{array}$ & $\begin{array}{l}\text { Pemberian } \\
\text { tindakan }\end{array}$ & $\begin{array}{l}\text { Variabel } \\
\text { Bebas }\end{array}$ & $\begin{array}{l}\text { Variabel } \\
\text { terikat }\end{array}$ \\
\hline 1 & $\begin{array}{l}\text { Dayang diah } \\
\text { martia sari } \\
(2017)\end{array}$ & MTS & $\begin{array}{l}\text { Pembelajaran } \\
\text { NOVICK }\end{array}$ & Model pembelajaran NOVICK & Hasil belajar \\
\hline 2 & $\begin{array}{l}\text { Nurlailatul } \\
\text { qadar (2016) }\end{array}$ & SMA & $\begin{array}{l}\text { Pembelajaran } \\
\text { berbasis } \\
\text { konstruktivisme }\end{array}$ & $\begin{array}{l}\text { Pembelajaran berbasis } \\
\text { konstruktivisme }\end{array}$ & $\begin{array}{l}\text { Kompetensi } \\
\text { TIK }\end{array}$ \\
\hline 3 & $\begin{array}{l}\text { Nurul } \\
\text { elkatiri } \\
(2017)\end{array}$ & SMK & $\begin{array}{l}\text { Pembelajaran } \\
\text { berbasis } \\
\text { konstruktivisme }\end{array}$ & $\begin{array}{l}\text { Pembelajaran berbasis } \\
\text { konstruktivisme menggunakan } \\
\text { media learning of fluida }\end{array}$ & $\begin{array}{l}\text { Respon } \\
\text { siswa }\end{array}$ \\
\hline 4 & $\begin{array}{l}\text { Sri devi } \\
(2017)\end{array}$ & MTS & $\begin{array}{l}\text { Pembelajaran } \\
\text { quantum teaching }\end{array}$ & $\begin{array}{l}\text { Model pembelajaran quantum } \\
\text { teaching }\end{array}$ & Hasil belajar \\
\hline 5 & $\begin{array}{l}\text { Ummi } \\
\text { kalsum } \\
(2017)\end{array}$ & SMK & $\begin{array}{l}\text { Pembelajaran } \\
\text { berbasis } \\
\text { konstruktivisme }\end{array}$ & $\begin{array}{l}\text { Pembelajaran berbasis } \\
\text { konstruktivisme menggunakan } \\
\text { temperature interactive } \\
\text { multimedia }\end{array}$ & $\begin{array}{l}\text { Respon } \\
\text { siswa }\end{array}$ \\
\hline
\end{tabular}


Tabel 1 menyajikan data penelusuran hasil penelitian yang dijadikan sebagai subjek dalam penelitian ini. Identidas yang disajikan pada Tabel 1 melipiti Jenjang pendidikan subjek, Pemberian tindakan, variabel bebas dan variabel terikat.

\section{Penilaian Kualitas Artikel}

Pada tahap ini dilakukan penilaian kualitas artikel untuk memperoleh subjek penelitian. Hasil penilaian kualitas artikel yang dilakukan oleh peneliti disajikan pada Tabel 2.

Tabel 2 Hasil Penilaian Artikel

\begin{tabular}{|c|c|c|c|c|c|}
\hline No & Nama peneliti/tahun & $\begin{array}{c}\text { Jenjang pendidikan } \\
\text { subjek } \\
\end{array}$ & \multicolumn{2}{|c|}{ Pemberian tindakan } & Penilaian \\
\hline 1 & $\begin{array}{l}\text { Dayang Diah Martia } \\
\text { Sari (2017) }\end{array}$ & MTS & \multicolumn{2}{|c|}{ Pembelajaran NOVICK } & 200 \\
\hline 2 & $\begin{array}{l}\text { Nurlailatul Qadar } \\
\text { (2016) }\end{array}$ & SMA & $\begin{array}{l}\text { Pembelajaran } \\
\text { konstruktivisme }\end{array}$ & berbasis & 250 \\
\hline 3 & Nurul Elkatiri (2017) & SMK & $\begin{array}{l}\text { Pembelajaran } \\
\text { konstruktivisme }\end{array}$ & berbasis & 200 \\
\hline 4 & Sri Devi (2017) & MTS & $\begin{array}{l}\text { Pembelajaran } \\
\text { teaching }\end{array}$ & quantum & 176 \\
\hline 5 & Ummi Kalsum (2017) & SMK & $\begin{array}{l}\text { Pembelajaran } \\
\text { konstruktivisme }\end{array}$ & berbasis & 187 \\
\hline
\end{tabular}

Dari penilaian kualitas artikel kemudian di peroleh 5 buah artikel. Penilaian kualitas artikel mengikuti format penilaian karya ilmiah.

\section{Menggabungkan Hasil Penelitian}

Setelah dilakukan penilaian kualitas artikel, selanjutnya dilakukan penggabungan hasil penelitian. Berikut disajikan penggabungan hasil penelitian berdasarkan tinjauan di atas.

\section{a) Ditinjau dari Pemberian Tindakan}

Tabel 3. Penggabungan artikel ditinjau dari pemberian tindakan

\begin{tabular}{|c|c|c|c|c|c|}
\hline No & Nama peneliti/tahun & $\begin{array}{c}\text { Pemberian } \\
\text { tindakan }\end{array}$ & $\begin{array}{c}\text { Variabel } \\
\text { Bebas } \\
\end{array}$ & $\begin{array}{c}\text { Variabel } \\
\text { terikat }\end{array}$ & Rerata \\
\hline $\mathbf{1}$ & $\begin{array}{l}\text { Dayang Diah Martia } \\
\text { Sari (2017) }\end{array}$ & $\begin{array}{l}\text { Pembelajaran } \\
\text { NOVICK }\end{array}$ & Model pembelajaran NOVICK & Hasil belajar & 74,67 \\
\hline 2 & Nurul Elkatiri (2017) & $\begin{array}{l}\text { Pembelajaran } \\
\text { berbasis } \\
\text { konstruktivisme }\end{array}$ & $\begin{array}{l}\text { Pembelajaran berbasis } \\
\text { konstruktivisme menggunakan } \\
\text { media learning of fluida }\end{array}$ & Respon siswa & $77,70 \%$ \\
\hline 3 & Sri Devi (2017) & $\begin{array}{l}\text { Pembelajaran } \\
\text { quantum teaching }\end{array}$ & $\begin{array}{l}\text { Model pembelajaran quantum } \\
\text { teaching }\end{array}$ & Hasil belajar & 68,86 \\
\hline 4 & Ummi Kalsum (2017) & $\begin{array}{l}\text { Pembelajaran } \\
\text { berbasis } \\
\text { konstruktivisme }\end{array}$ & $\begin{array}{l}\text { Pembelajaran berbasis } \\
\text { konstruktivisme menggunakan } \\
\text { temperature interactive } \\
\text { multimedia }\end{array}$ & Respon siswa & $70,29 \%$ \\
\hline
\end{tabular}




\section{b) Ditinjau dari Tingkat Pendidikan Subjek}

Pada tahap ini dilakukan penggabungan artikel bersasarkan tingkat pendidikan subjek. Penggabungan artikel disajikan pada Tabel 4 dan Tabel 5.

Tabel 4 Penggabungan artikel ditinjau dari tingkat pendidikan subjek SMA/SMK Sederajat

\begin{tabular}{|c|c|c|c|c|c|}
\hline No & $\begin{array}{c}\text { Nama } \\
\text { peneliti/tahun }\end{array}$ & $\begin{array}{c}\text { Jenjang } \\
\text { pendidikan } \\
\text { subjek } \\
\end{array}$ & $\begin{array}{l}\text { Variabel } \\
\text { Bebas }\end{array}$ & $\begin{array}{c}\text { Variabel } \\
\text { terikat }\end{array}$ & Rerata \\
\hline 1 & $\begin{array}{l}\text { Nurul Elkatiri } \\
(2017)\end{array}$ & SMK & $\begin{array}{l}\text { Pembelajaran berbasis } \\
\text { konstruktivisme } \\
\text { menggunakan media learning } \\
\text { of fluida }\end{array}$ & $\begin{array}{l}\text { Respon } \\
\text { siswa }\end{array}$ & $77,70 \%$ \\
\hline 2 & $\begin{array}{l}\text { Ummi Kalsum } \\
\text { (2017) }\end{array}$ & SMK & $\begin{array}{l}\text { Pembelajaran berbasis } \\
\text { konstruktivisme } \\
\text { menggunakan temperature } \\
\text { interactive multimedia }\end{array}$ & $\begin{array}{c}\text { Respon } \\
\text { siswa }\end{array}$ & $70,29 \%$ \\
\hline
\end{tabular}

Tabel 5 Penggabungan artikel ditinjau dari tingkat pendidikan subjek SMP/MTS Sederajat

\begin{tabular}{cccccc}
\hline No & $\begin{array}{c}\text { Nama } \\
\text { peneliti/tahun }\end{array}$ & $\begin{array}{c}\text { Jenjang } \\
\text { pendidikan } \\
\text { subjek }\end{array}$ & \multicolumn{1}{c}{$\begin{array}{c}\text { Variabel } \\
\text { Bebas }\end{array}$} & $\begin{array}{c}\text { Variabel } \\
\text { terikat }\end{array}$ & Rerata \\
\hline $\mathbf{1}$ & $\begin{array}{l}\text { Dayang Diah Martia } \\
\text { sari (2017) }\end{array}$ & MTS & Model pembelajaran novick & Hasil belajar & 74,67 \\
\hline $\mathbf{2}$ & Sri Devi (2017) & MTS & $\begin{array}{l}\text { Model pembelajaran } \\
\text { quantum teaching }\end{array}$ & Hasil belajar & 68,86 \\
\hline
\end{tabular}

\section{Penggabungan hasil dalam} penelitian ini akan dikelompokkan antara lain ditinjau berdasarkan; a. Pemberian tindakan; b. Tingkat pendidikan subjek; c. Respon Siswa. Penelitian ini juga menyajikan besar Pengaruh Model berbasis Konstruktivisme berdasarkan Pemberian Tindakan dan disajikan pada Tabel 6.

Tabel 6. Besar pengaruh pemberian tindakan berbasis Konstruktivisme

\begin{tabular}{ccc}
\hline Statistik & $\begin{array}{c}\text { Model } \\
\text { NOVICK }\end{array}$ & $\begin{array}{c}\text { Model Quantum } \\
\text { Teaching }\end{array}$ \\
\hline$d$ & 2,03 & 1,32 \\
\hline
\end{tabular}

Keterangan :

$d=$ besar pengaruh (Effect size) pemberian tindakan.

\section{Pembahasan}

Tabel 3 menyatakan bahwa pemberian tindakan berupa pembelajaran berbasis konstruktivisme tipe novick lebih unggul dikbandingkan dengan tipe quantum teaching. Dibuktikan dengan data pembelajaran berbasis konstruktivisme tipe novick memperoleh rerata 74,67 sedangkan pada tipe quantum teaching memperoleh rerata 68,86 . Berdasarkan Tabel 3 juga diketahui bahwa pemberian tindakan berupa pembelajaran berbasis konstruktivisme mendapatkan respon kategori baik dari 
siswa dengan perolehan persentase sebesar $77,70 \%$ dan 70,29\%.

Pemberian tindakan berupa pembelajaran berbasis konstruktivisme pada siswa MTS mendapatkan hasil belajar pada kategori baik ditunjukkan oleh Tabel 5, di mana diperoleh data dengan rerata hasil belajar sebesar 74,67 dan 68,86. Berdasarkan Tabel 4 diperoleh data bahwa pemberian tindakan berupa pembelajaran berbasis konstruktivisme pada siswa SMK mendapatkan respon kategori baik dengan perolehan persentase sebesar $77,70 \%$ dan $70,29 \%$. Hal ini juga didukung oleh penelitian Sumarsih bahwa pembelajaran berbasis konstruktivisme baik degunakan dalam pembelajaran bisnis (Sumarsih, 2009).

Pemberian tindakan berupa pembelajaran berbasis konstruktivisme menggunakan media pada siswa SMK mendapatkan respon kategori baik dengan perolehan persentase sebesar 77,70\% dan 70,29\% ditunjukkan oleh Tabel 3. Berdasarkan kriteria Cohen maka pembelajaran berbasis konstruktivisme memiliki pengaruh besar terhadap peningkatan hasil belajar siswa yang diberikan perlakuan menggunakan model novick dan quantum teaching (Tabel 6). Hal senada juga diungkapkan melalui penelitian Nurul dkk bahwa penggunaan pendekatan konstruktivisme pada pembelajaran Matematika berhasil meningkatkan keaktifan dan hasil belajar siswa (Chujaemah et al., 2013).

\section{SIMPULAN DAN SARAN Simpulan}

Berdasarkan hasil penelitian yang telah diperoleh, maka kesimpulan yang dapat diambil dari hasil penelitian adalah: 1) Rerata pembelajaran berbasis konstruktivisme ditinjau dari jenjang pendidikan subjek penelitian berkategori baik; 2) Rerata hasil belajar dan respon siswa dari pembelajaran berbasis konstruktivisme ditinjau dari pemberian tindakan berkategori baik; 3) Rerata pengaruh pembelajaran berbasis konstruktivisme terhadap variabel terikat subjek penelitian berkategori baik.

\section{Saran}

Meta analisis dapat digunakan untuk melihat tingkat konsistensi atau tidak konsisten suatu penelitian pada tingkat yang dipilih.

\section{UCAPAN TERIMA KASIH}

Ucapan terimakasih kepada Ristek Dikti atas dukungan pembiayaan SK. Jendral Penguatan Riset dan Pengembangan Nomor 01/E/KPT/2017.

\section{DAFTAR PUSTAKA}

Abdurrahman. (2017). Efektivitas dan Kendala Pembelajaran Sains Berbasis Inkuiri terhadap Capaian Dimensi Kognitif Siswa: Meta Analisis. Tadris: Jurnal Keguruan Dan Ilmu Tarbiyah, 2(1), 1-9.

Ariesta, R., \& Supartono. (2011). Pengembangan Perangkat Perkuliahan Kegiatan Laboratorium Fisika Dasar II Berbasis Inkuiri Terbimbing untuk Meningkatkan Kerja Ilmiah Mahasiswa. Jurnal Pendidikan Fisika Indonesia, 7(1), 62-68.

Chujaemah, N., Yuliana, S., Utaminingsih, S., Triyono, \& Budi, H. S. (2013). Penggunaan Pendekatan Konstruktivisme dalam Peningkatan Hasil Belajar Matematika Siswa Kelas IV Materi Bangun Ruan. Kalam Cendekia PGSD Kebumen, 1(2), 1-7.

Erlinda, N. (2017). Peningkatan Aktivitas dan Hasil Belajar Siswa melalui Model Kooperatif Tipe Team Game Tournament pada Mata Pelajaran Fisika di SMK. Tadris: Jurnal Keguruan Dan Ilmu Tarbiyah, 2(1), 47-52.

Maryam, I. (2016). Surya Edukasi : Pengaruh Pembelajaran Open-Ended Dan Konstruktivis Terhadap Prestasi Belajar Matematika Ditinjau Dari 
Motivasi Belajar Siswa 26. Jurnal Pendidikan Surya Edukasi, 26-41.

Matthew, B. M., \& Kenneth, I. O. (2013). A Study on The Effects of Guided Inquiry Teaching Method on Students Achievement in Logic. International Researchers, 2(1), 133-140.

Nawawi, H. (2007). Metode Penelitian Bidang Sosial. Yogyakarta: Gajah Mada University Press.

Nurussaniah, \& Nurhayati. (2016). Pengembangan Penuntun Praktikum Fisika Dasar 1 Berbasis Guided Inquiry Untuk Meningkatkan Kemampuan Berpikir Kritis Mahasiswa. Priosiding Seminar Nasional Fisika (E-Journal), V, 6368.

Rerung, N., Sinon, I. L. S., \& Widyaningsih, S. W. (2017). Penerapan Model Pembelajaran Problem Based Learning (PBL) untuk Meningkatkan Hasil Belajar Peserta Didik SMA pada Materi Usaha dan Energi. Jurnal Ilmiah Pendidikan Fisika Al-Biruni, 6(April), 47-55.

Rini, P. (2017). Efektivitas Model Problem Based Learning dalam Mereduksi Disparitas Gender pada Capaian Pembelajaran Sains. Jurnal Ilmiah Pendidikan Fisika Al-Biruni, 6(1), 57.

Saregar, A., Latifah, S., \& Sari, M. (2016). Efektivitas Model Pembelajaran CUPs: Dampak terhadap Kemampuan Berpikir Tingkat Tinggi Peserta Didik Madrasah Aliyah Mathla'ul Anwar Gisting Lampung. Jurnal Ilmiah Pendidikan Fisika Al-Biruni, 5(2), 233-243.

Suciati. (2010). Membangun Karakter Peserta Didik Melalui Pembelajaran Biologi Berbasis Keterampilan Proses. In Prosiding Seminar Nasional VII Pendidikan Biologi FKIP UNS.
Sukamto. (1988). Perencanaan \& Pengembangan Kurikulum Pendidikan Teknologi dan Kejuruan. Sukiman. (2008). Teori Pembelajaran Dalam Pandangan Konstruktivisme dan Pendidikan Islam. Kependidikan Islam, 3(1), 59-70.

Sumarsih. (2009). Implementasi Teori Pembelajaran Konstruktivistik Dalam Pembelajaran Mata Kuliah Dasar-Dasar Bisnis. Pendidikan Akutansi Indonesia, VIII(1), 54-62.

Sutjipto, H. . (1995). Aplikasi Metaanalisis dalam Pengujian Validitas Item. Yogyakarta: Fakultas Psikologi UGM.

Syamsu, F. D. (2017). Pengembangan Penuntun Praktikum IPA Berbasis Inkuiri Terbimbing untuk Siswa SMP Siswa Kelas VII Semester Genap. BIOnatural, 4(2), 13-27.

Ummi, H. U., \& Mulyaningsih Indrya. (2016). Penerapan Teori Konstruktivistik Pada Pembelajaran Bahasa Arab di IAIN Syekh Nurjati Cirebon. Journal Indonesian Language Education and Literature, 1(2), 42-52.

Wati, W., \& Fatimah, R. (2016). Effect Size Modul Pembelajaran Kooperatif Tipe Numbered Heads Together (NHT) terhadap Kemampuan Berpikir Kritis Siswa pada Pembelajaran Fisika. Jurnal Ilmiah Pendidikan Fisika Al-Biruni, 5(2), 213-222. 